\title{
Nieuwe en oude dingen
}

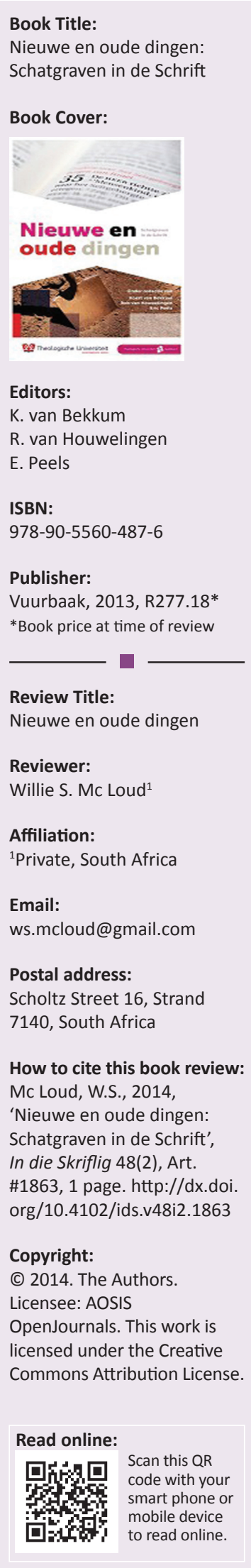

Nieuwe en oude dingen, onder redaksie van Koert van Bekkum, Rob van Houwelingen en Eric Peels, bring die gewone lekeleser op die hoogte aangaande kontemporêre gesprekke (nieuwe dingen) asook ontwikkelings oor die afgelope 100 jaar (oude dingen) in die gereformeerde Bybelwetenskap by die Nederlandse universiteite in Kampen en Apeldoorn.

Alhoewel die bydraers soms die klem verskillend laat val, is die oogmerk by hierdie universiteite om die Bybelwetenskap op 'n Skrifgetroue wyse te beoefen in samehang met geesgenote uit die Evangeliese en Presbiteriaanse tradisies. Daar word gepoog om 'n middeweg te vind tussen die simplisiteit, as 'n kenmerk van die Fundamentalisme, en die Kritiese Bybelwetenskap wat weer spanning skep in die geloof in die inspirasie van die Bybel en die belydenis dat die Skrif God se Woord is.

Die bydraes wat in hierdie boek opgeneem is, handel oor ' $n$ verskeidenheid relevante en eietydse kwessies. Alhoewel die Skrifkritiese lesing verwerp word, is daar wel 'n kritiese bestudering van die historiese prosesse waarin en die menslike wyse waarop die Bybel as heilige teks tot stand gekom het. Alhoewel dit in die Skrif primêr oor die openbaring van God aan die mens gaan, is daar volle erkenning dat die Bybel deur mense tot stand gekom het.

Die boek volg 'n drieledige indeling waarin die kanon, die outeurskap en die boodskap van die Bybel onder die loep kom. Binne hierdie raamwerk word 'n verskeidenheid temas deur die onderskeie bydraers hanteer, waaronder die tydvak waarin die Ou-Testamentiese kanon as afgehandel beskou is, die invloed van die Septuaginta op die Nuwe-Testamentiese denke (veral in die boek Hebreërs), die herinterpretasie van Ou-Testamentiese profesieë in die boek Openbaring waar Rome as die nuwe Tirus uitgebeeld word, die skryfkuns en skrywers in die antieke tyd, die eenheid en die outeurskap in die boek Jesaja, apostoliese outeurskap in die Nuwe Testament, volksmoord in die naam van God en nog meer.

Die boek is tydig in die lig van die feit dat die formele studie van die Bybel oor die afgelope halfeeu al meer in verskillende benaderings vertak het. Dit plaas 'n duidelike alternatief vir die Kritiese Bybelwetenskap op die tafel. Die Kritiese Bybelwetenskap gaan steeds gekniehalter onder modernistiese wortels. Voorts bied dit 'n alternatief vir die postmoderne stroom in die Bybelwetenskap. Tog tree Nieuwe en oude dingen nie direk in gesprek met die ander benaderings nie en geen argumente word aangebied waarom hierdie behoudende benadering op akademiese gronde verkies behoort te word nie. Alhoewel 'n Skrifgebaseerde lees van die teks nagestreef word, kan 'n mens steeds wonder in watter opsig hierdie benadering akademies voortrefliker is as die ander alternatiewe. Ek sou dink dat hierdie saak meer aandag in die boek moes kry.

Oor die algemeen is die bydraes in 'n gemaklik leesbare trant geskryf (ook vir die Afrikaanse lesers) en enigeen wat in hierdie gesprekke geïnteresseerd is, sal beslis by die boek baat vind. Daar is sekerlik ' $n$ behoefte aan akademiese leesstof wat hierdie middelweg in die godsdiensgesprek navolg. 